\title{
MGNREGA IN ASSAM: WHO ARE TAKING UP EMPLOYMENT?
}

\author{
Prerona Baruah* \\ and \\ Anjali Radkar**
}

\begin{abstract}
The Mahatma Gandhi National Rural Employment Guarantee Act (MGNREGA) is functional in almost all rural districts of India guaranteeing wage employment on demand. The main intention behind launching MGNREGA was to provide some minimum level of employment security to the poorest rural households. However, it has been found that only a fraction of households registered under the Act actually demands employment. This paper studies the latter for some distinctive socio-economic characteristics so as to deduce targeting efficiency of MGNREGA across India in general and in the State of Assam in particular. Findings of the paper suggest that it is the poorer and underprivileged regions as well as households who constitute the bulk of those demanding MGNREGA employment. Low income, poor material conditions, social backwardness, low levels of literacy and absence of stable source of income have been found to be significant in determining MGNREGA participation. Moreover, there is considerable participation by people past the conventional working age of 65 years as well as from women who are otherwise not part of the formal workforce. Thus, it is found that MGNREGA is reaching out to most of its intended beneficiaries, i.e., people who are prone to high degree of livelihood insecurities.
\end{abstract}

\section{Introduction}

In 2005 the Government of India (Gol) announced a social security programme larger in scope and coverage than any such previous programme. The "National Rural Employment Guarantee Act or Scheme" (NREGA or NREGS), which was implemented in three phases (Phase I: 2005-06; Phase II: 2007-08 and Phase III: 200809) across all rural districts of India, ${ }^{1}$ today poses as an alternative wage employment avenue in rural India and guarantees 100 days employment on demand to rural households.

The scheme was greeted by both praise and censure from academicians, bureaucrats, politicians and social leaders. One particular aspect which has remained a constant subject of debate relates to beneficiaries of MGNREGA, i.e., which sections of rural population are taking up employment underMGNREGA? Thevery purpose

*Research Scholar, Department of Humanities and Social Sciences, IIT-Guwahati.

**Associate Professor, Gokhale Institute of Politics and Economics, Pune. 
of this ambitious scheme would stand defeated if intended beneficiaries have not sought employment in significant numbers. An objective assessment of the above has become even more relevant todayastheGovernment of India istaking steps to strengthen the scheme further. J ha et al. (2008) studied the targeting efficiency of NREGS in Rajasthan and found that disadvantaged groups like scheduled tribes (STs) and landless households had significantly high probabilities of participating in NREGS. However,the poorest households had relatively lower probability of participation than households owning moderate quantities of land and those self-employed in agriculture. Dreze and Khera (2009) reported that widows and single women were especially appreciative of NREGA because of the opportunity to earn close to their homes. A study by Dutta, et al. (2012) found targeting performance of NREGS varied across States, with generally higher participation rates among the poor, along with several households that were just above official poverty line. Literature on NREGA participation in Assam is relatively limited. Bordoloi (2011) found that the scheme offered job opportunities for unskilled workable population and provided hard cash to the needy. Singha and Boroowa (2013) in a study found that participation of BPL households in NREGS was very low. Households who owned and / or cultivated land were joining the scheme in greater number than landless poor people. Lower wage rate and late payment of wages made the scheme less preferable to the poor and landless sections of society.

The present paper attemptsto study those sections of rural population who have taken up employment under MGNREGS in India as a whole and the north eastern State of Assam in particular. Assam's performance with regard to implementation of MGNREGS is average on several parameters like total employment generated, persondays of work provided per household, proportion of registered households in districts covered, etc., (Drèze and Oldiges, 2007; Bordoloi, 2011; Singha and Boroowa, 2013). Assam has remained an economically backward State for decades. A high proportion (79.8 per cent) of its rural workforce is engaged in agriculture ${ }^{2}$ and 67.32 percent of theState's total operational landholdings are marginal ${ }^{3}$ (average size 0.6 Ha). Latest estimates (2009-10) show that poverty rate in rural Assam isvery high at almost 40 per cent (Economic Survey of Assam, 2013). These observations indicate that a large section of the population suffers from livelihood insecurity and these people are potential MGNREGS beneficiaries. However, the important question here is whether the intended beneficiaries are the actual participants in the scheme.

\section{Objectives}

The study assesses the socio-economic features of the population participating (demanding employment) in MGNREGS in order to determine whether the scheme has been efficiently targeted across the country in general and in Assam in particular. It has attempted to determine the influence of a select set of socioeconomic characteristics on the extent of participation in MGNREGA during the reference period (2012-13) and examine whether the characteristics found significant at the national level have influence on the extent of participation in Assam. Furthermore, to substantiate its findings, the study has undertaken some primary data 
investigation through visits to three MGNREGS worksites in Dibrugarh district of Assam. The aim is to dissect socio-economic composition of workers at sites and relate the same with inferences drawn from previous analysis. Although the sample size is small, the primary data analysis has given insights on the ground realities. One main objective in including this primary analysisis to investigate inconsistencies, if any, between the ground realities and the indications from the secondary data.

\section{Methodology}

The study is analytical in approach. Data are tabulated across different parametres to identify broad patterns. Regression analysisisused to find out direction and magnitude of influence of select socio-economic variables on the level of demand for employment under the scheme.

All secondary data used were accessed from credible official sources: Ministry of Rural Development's (MORD) official website of NREGA (http://www.nrega.nic.in); Census of India,2011 (http://www.censusindia.gov.in); Economic Survey of Assam (GoA 2012-13), Directorate of Economics and Statistics, Assam; Ministry of Statistics and Programme Implementation (MoSPI), etc. Although MGNREGS was operational in 636 rural districts of the country during 201213 , only 586 districts were considered because of the differences between MGNREGS and Census of India records for the remaining districts. The compiled secondary data were subjected to some adjustments to make them comparable, as shown in Appendix 2.

Primary data were collected through visits to the population of three MGNREGS worksites in Barbaruah block of Dibrugarh district of Assam in November, 2013. Details are provided in Appendix 1. Care is taken to ensure that each village is different from others in terms of economic and population characteristics. Data were collected through one-on-one interviews with workers present at the site on several aspects like age, sex, literacy, earners, latrine facility, asset ownership, income sources, consumption-expenditure, land ownership, year of registration, number of registered household (hh) members and reasonsfor opting MGNREGS employment. In addition, a focusgroup discussion (FGD) was conducted with both panchayat and block officials.

\section{Findings}

Findings from Secondary Data Analysis: This section analyses the characteristics of the population that demanded employment under MGNREGA across the country as a whole and in the State of Assam in particular. Data available through management information system (MIS) of MGNREGA (www.nrega.nic.in)show that States differ with respect to extent of registration and participation and in several regions a much smaller proportion of registered persons actually demanded employment under the scheme. Careful analysis shows that percentage of registered households and employment demand is quite low in States and Union Territories which had per capita net state domestic product (NSDP) higher than county's per capita net national income of $₹ 38005$ at constant (2004-05) prices during 2011-12 like Chandigarh, Goa, Haryana, Punjab,Puducherry, Maharashtra, Gujarat, Kerala, Karnataka, Tamil Nadu and Andaman \& Nicobar 
islands. On the other hand, opposite was true for States with per capita NSDP below national average like Madhya Pradesh, Assam, Manipur, Rajasthan, Chhattisgarh, Mizoram,
Jharkhand and Odisha (Figure 1).This indicates that NREGA employment has been sought more by persons from poorer and less developed regions.

\section{Figure 1: NSDP Per Capita and NREGA Participation (India)}

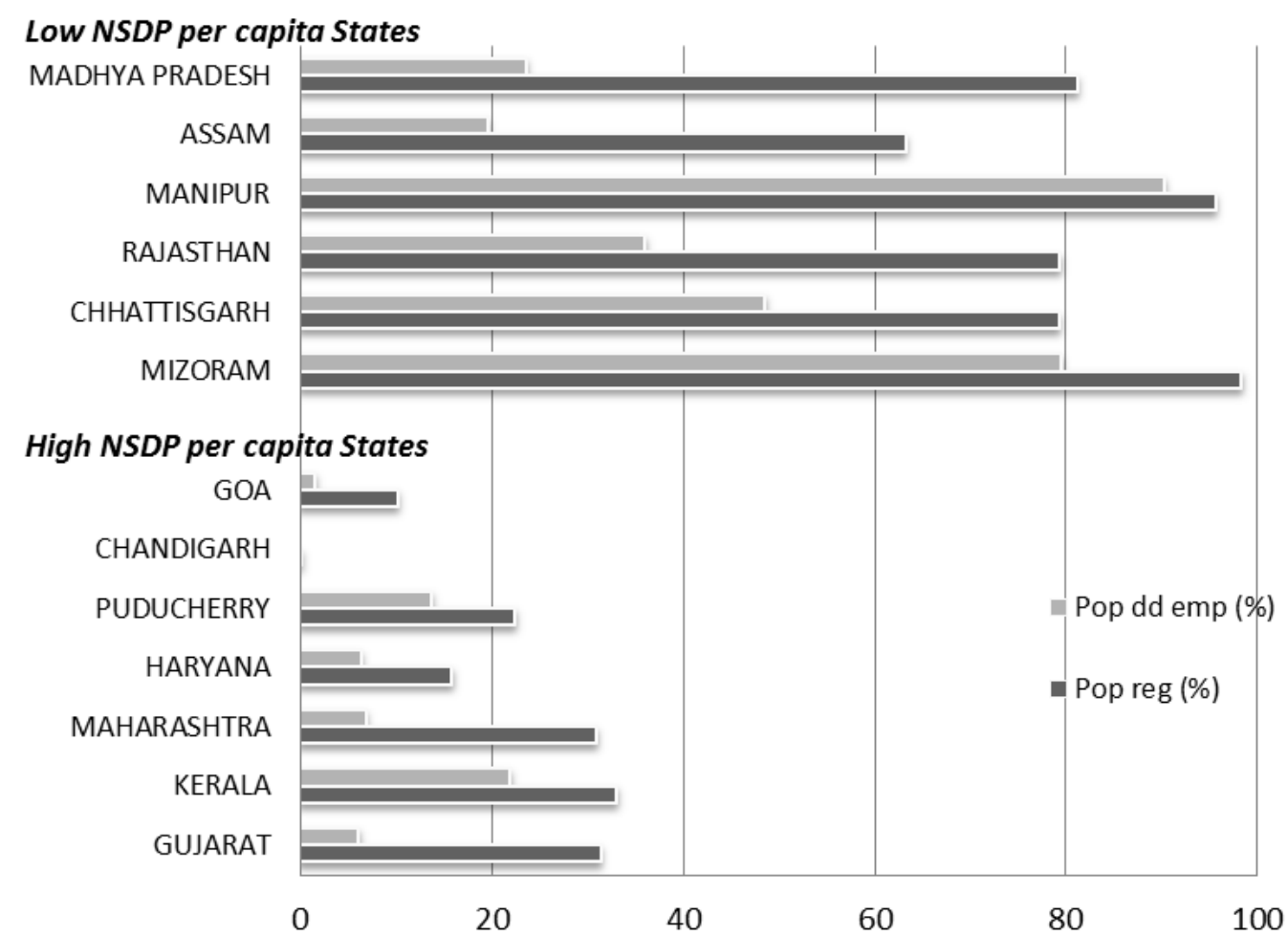

Source: Compiled from www.nrega.nic.in and MoSPI [http://mospi.nic.in/Mospi_New/upload/ State_wise_SDP_2004-05_14mar12.pdf].

Observations made about Assam also conform to the national picture. Assam had atotal of 27 districts at the time when this study was undertaken ${ }^{4}$. In Sivasagar, Dibrugarh,J orhat and Tinsukia districts with per capita net district domestic product (NDDP) which is higher than the State's per capita net domestic product, the percentage of population/households registered and/or demanding employment is relatively low. On the other hand, registration/demand ishigher in Chirrang, Dhemaji and Barpeta, which have per capita NDDP much lower than per capita NSDP of Assam.

Another important factor influencing the extent of registration and employment in districts is time, i.e., length of exposure to NREGA. A 
comparison of percentage of total rural households and population (aged 18 years and above) ${ }^{5}$ registered (and demanding employment) showsthat, on an average, figures were higher for those districts which were included under NREGA in the first phase (2005) and lowest for districts which were included in the last phase $(2008)^{6}$. Figure 2 demonstrates clear differences in participation among households in Phase I and Phase III districts.

\section{Figure 2: Differences in NREGA Participation Across Phase I and Phase III Districts (Assam) during 2012-13}

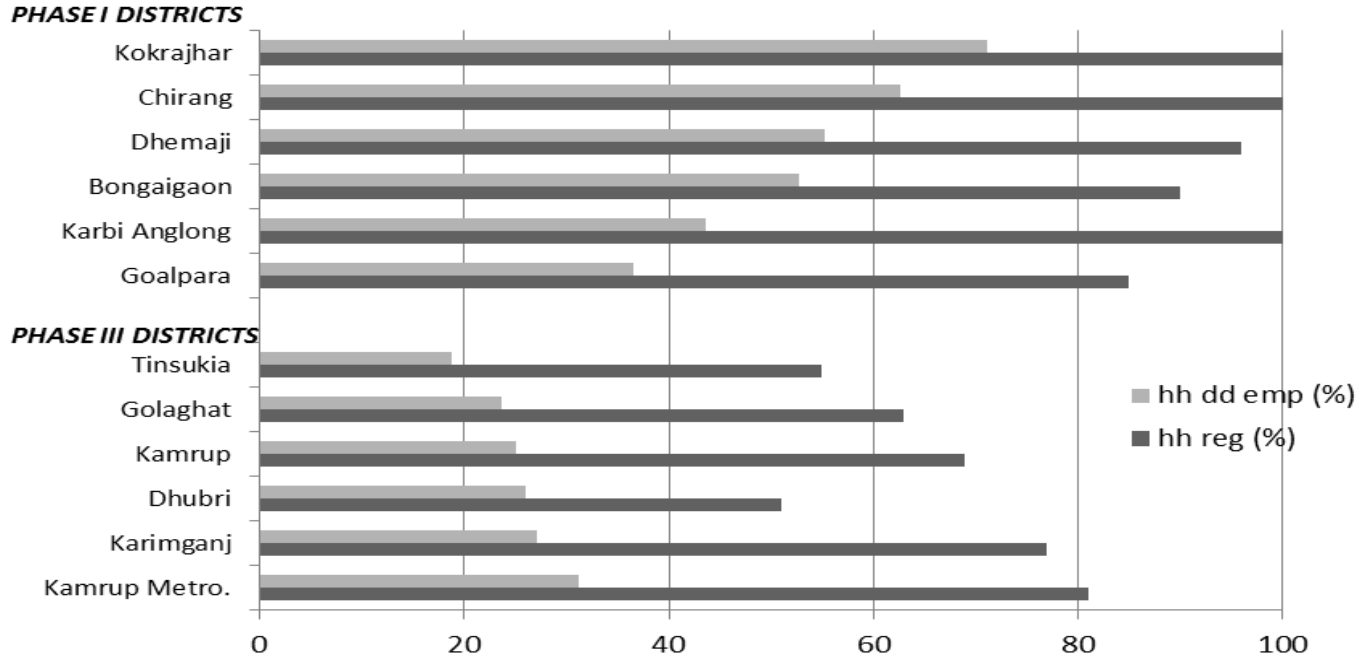

Source: Tabulated from data available on www.nrega.nic.in.

\begin{tabular}{llc}
\hline & District & Percentage of Total Population Demanding Employment \\
\hline 1. & Kokrajhar & 23.60 \\
2. & Dhemaji & 21.58 \\
3. & Baksa & 17.33 \\
4. & Chirang & 17.23 \\
5. & Morigaon & 17.10 \\
6. & Goalpara & 15.90 \\
7. & Bongaigaon & 15.40 \\
8. & KarbiAnglong & 15.29 \\
9. & Hailakandi & 11.04 \\
10. & Sonitpur & 10.80 \\
11. & Sivasagar & 10.66 \\
\hline
\end{tabular}

Journal of Rural Development, Vol. 36, No. 2, April - June: 2017 
Given below is a list of districts in Assam having higher than the State's average (10.01 per cent) percentage of total persons demanding employment under NREGA:

Out of eleven, six districts (Kokrajhar, Dhemaji, Chirrang, Bongaigaon, Karbi Anglong and Goalpara) were included under NREGA in Phase I. Thus, we find the districts identified as backward (Phase I) are actually seeing higher participation in NREGA than others.

Next, a more detailed analysis is undertaken to estimate the influence of some important households and demographic characteristics on NREGA participation at national level. A linear regression model has been used on district level data (covering 586 districts) for 2012-13, which can be written as:
$Y=\beta_{0}+\beta_{1}\left(X_{1}\right)+\beta_{2}\left(X_{2}\right)+$ $+\beta_{7}\left(X_{7}\right)+\beta_{8}\left(X_{8}\right)+\mu$

The choice of explanatory variables is guided by economic theory and existing literature. It is expected that the material wellbeing of households will be reflected in the physical state of their residence/ living conditions, their asset holdings, level of formal education, stability of their income sources and their access to formal institutions like banks. Households belonging to lower economic strata will not perform well on these aspects. Furthermore, in India, it is found that households belonging to the scheduled caste (SC) and the scheduled tribe (ST) communities are deprived of economic opportunities irrespective of their material condition. Hence, they are also analysed in the model. Details of variables used are provided in Appendix 3. Results of the regression are tabulated in Table 1.

Table 1: Results of Linear Regression

\begin{tabular}{|c|c|c|c|c|c|}
\hline \multicolumn{4}{|c|}{$\begin{array}{l}\text { Dependent Variable: Percentage of Persons Worked } \\
\text { under NREGA }\end{array}$} & \multicolumn{2}{|c|}{$\begin{array}{r}N=586 \\
R=0.472^{a} \\
R^{2}=0.223 \\
F=20.654 \\
\text { Sig. }(p)=0.000^{a}\end{array}$} \\
\hline Var & Variable name (Predictor) & Co-efficient ( $\beta$ ) & Std. Err. & $\mathrm{t}$ & p (sig.) \\
\hline$\beta_{0}$ & (Constant) & 8.386 & 1.735 & 4.834 & .000 \\
\hline$X_{1}$ & Houses dilapidated & -.471 & .115 & -4.086 & .000 \\
\hline$x_{2}^{1}$ & No assets owned & .013 & .040 & .338 & .735 \\
\hline$x_{3}^{2}$ & No latrine facility & .004 & .018 & .224 & .823 \\
\hline$x_{4}^{3}$ & No baking facility access & .055 & .020 & 2.804 & .005 \\
\hline$x_{5}^{4}$ & Illiterates & -.148 & .053 & -2.770 & .006 \\
\hline$x_{6}$ & $\mathrm{SC}$ & .143 & .049 & 2.889 & .004 \\
\hline$x_{7}^{0}$ & ST & .168 & .021 & 8.059 & .000 \\
\hline$x_{8}^{\prime}$ & Agri labourers & .052 & .036 & 1.444 & .149 \\
\hline
\end{tabular}

(For Definitions See Appendix 3) 
An $F$ value of 20.654 with $p$ value of 0.000 implies that the model as a whole is statistically significant. Five out of eight explanatory variables taken have been found to be significant at less than 1 percent level of significance. Among them, proportion of SC, ST and households without access to banking are positive, indicating that higher the presence of these characteristics in population of any district, more will be number of persons taking up employment under NREGA in that district.This isin line with our expectations. On the other hand, coefficients of the variables representing proportion of dilapidated households and illiterates have been found to be negative, which is against our expectation. Again, the variables representing absence of any assets owned and latrine facility along with proportion of agricultural labourers in total workersare not found to bestatistically significant. This indicates absence of clear unidirectional effect of the factors. Taken together, these two findings point to the fact that the study could not find strong evidence to support the claim that the districts that have higher proportion of households with poor material conditions witnessed higher participation in NREGA. Also, the fact that the proportion of illiterate population is found to be negative and significant needs further examination. This particular finding is against what was expected and is explored later in the study with the aid of primary data.

Coming to Assam, in the eleven districts that were identified as having a higher NREGA participation rate, some broad patterns in socioeconomic characteristics could be observed. Most of these districts have higher than the State's average proportion of ST population, illiterate (ignoring the population below theage of 7 years), workforce engaged as agricultural labourers and households in dilapidated residence conditions with no latrine facility within premises. On the otherhand, these districts have alower proportion of households availing banking facilities, having either none or all of the considered assets? Important findings about demographic and household characteristics of these districts are provided in Table 2 .

Table 2: Distinctive Demographic and Household Characteristics of High NREGA Participation Districts (Assam)

\begin{tabular}{|c|c|c|}
\hline Characteristic & $\begin{array}{l}\text { State Average } \\
(\%)\end{array}$ & $\begin{array}{l}\text { Districts (\% of population) } \\
\text { Proportion found Higher than State Average }\end{array}$ \\
\hline STpopulation & 18.37 & $\begin{array}{l}\text { Karbi Anglong (58.3), Dhemaji (49.7), Chirang (39.5), } \\
\text { Baksa(35.2), Kokrajhar(32.1), Goalpara(25.3) }\end{array}$ \\
\hline Illiteratepopulation* & 25.48 & $\begin{array}{l}\text { Chirang (38), Bongaigaon (32.7), Kokrajhar } \\
\text { (30.6), Sonitpur (29.8), Hailakandi (28.6), } \\
\text { Goalpara (28.1), Karbi Anglong (27.9) } \\
\text { Morigaon (27.6), Baksa (26.8), Dhemaji (23.9) }\end{array}$ \\
\hline $\begin{array}{l}\text { Marginal agricultural } \\
\text { labourersin workforce }\end{array}$ & 8.78 & $\begin{array}{l}\text { Baksa (12.4), Goalpara (11.8), Karbi Anglong } \\
\text { (11.5), Morigaon(10.9), Chirang (10.5), } \\
\text { Bongaigaon(10.1), Sonitpur (9) }\end{array}$ \\
\hline
\end{tabular}


Table 2 (Contd.....)

\begin{tabular}{lcl}
\hline $\begin{array}{l}\text { Residence in dilapidated } \\
\text { conditions }\end{array}$ & 10.35 & $\begin{array}{l}\text { Hailakandi (15.9), Morigaon (14.1), Kokrajhar } \\
(12.3), \text { Goalpara (11.9), Baksa (11.1), } \\
\text { Bongaigaon (11), Chirang (11) }\end{array}$ \\
$\begin{array}{l}\text { No latrine facility within } \\
\text { premises }\end{array}$ & $\begin{array}{l}\text { Chirang (71.3), Kokrajhar (70.8), Baksa (60.6), } \\
\text { Dhemaji (55.2), Karbi Anglong (45.2), } \\
\text { Bongaigaon (43.7), Sonitpur(40.8), Morigaon } \\
(39.9)\end{array}$
\end{tabular}

\section{Proportion found lower than State average}

$\begin{array}{lcl}\begin{array}{l}\text { All considered assets } \\ \text { available }\end{array} & 1.87^{* *} & \begin{array}{l}\text { Hailakandi (0.6), Baksa (0.7), Chirang (1.1), } \\ \text { Goalpara (1.1), Karbi Anglong (1.2), Kokrajhar } \\ \text { (1.2), Morigaon (1.3), Dhemaji(1.4) }\end{array} \\ & & \begin{array}{l}\text { Baksa(15.9), Sonitpur (16.3), Sivasagar (17.7), } \\ \text { Dhemaji (19.1), Bongaigaon (19.2), Karbi } \\ \text { None of the considered }\end{array} \\ \text { assets available } & \begin{array}{l}\text { Anglong (20), Chirang (20.1), Kokrajhar } \\ (22.61)\end{array}\end{array}$

Availing banking services $\quad 44.09 \quad$ Baksa (33.6), Chirang (36.9), Dhemaji (35.7), Goalpara (33.3), Karbi Anglong (41.7),

*illiterates above the age of 6 years.

**Excluding Kamrup Metro which has an extremely high (17 per cent) share of households with all of the considered assets and therefore disproportionately distorts the State average.

The above findings for Assam point towards the inference that most persons who actually seek MGNREGA employment comefrom poorhouseholdswhose houses are in dilapidated conditions, have no latrine facility within their premises and no access to banking facilities. However, in terms of asset ownership, most of them do own some assets like television. When this is augmented with the findings at all-India level, it points towards the possibility that even though there is higher demand from the lower economic strata, it is relatively less worse, who participate more in MGNREGS. This claim requires further enquiry and can be taken up in subsequent researches. In terms of demographic characteristics, there is relatively higher demand from socially underprivileged sections like SCS and STs.Again, participation has been highest by those engaged asmarginal agricultural labourers, who represent the population without stable employment and income source. Also the influence of proportion of literates (or illiterates) on participation rate could be identified for Assam.

The study delves deeper into data regarding NREGA employment demand pattern in Assam by registered persons and households to explore any influence of district's workforce 
composition (or occupation type) on demand for NREGA employment over the years and finds a clear seasonality.Figure 3 plots average number of persons demanding NREGA employment in different months during last four financial years (average of 2009-10 to 2012-13).

Figure 3: General Pattern of Demand for Employment in Different Months in Assam (2010-13)

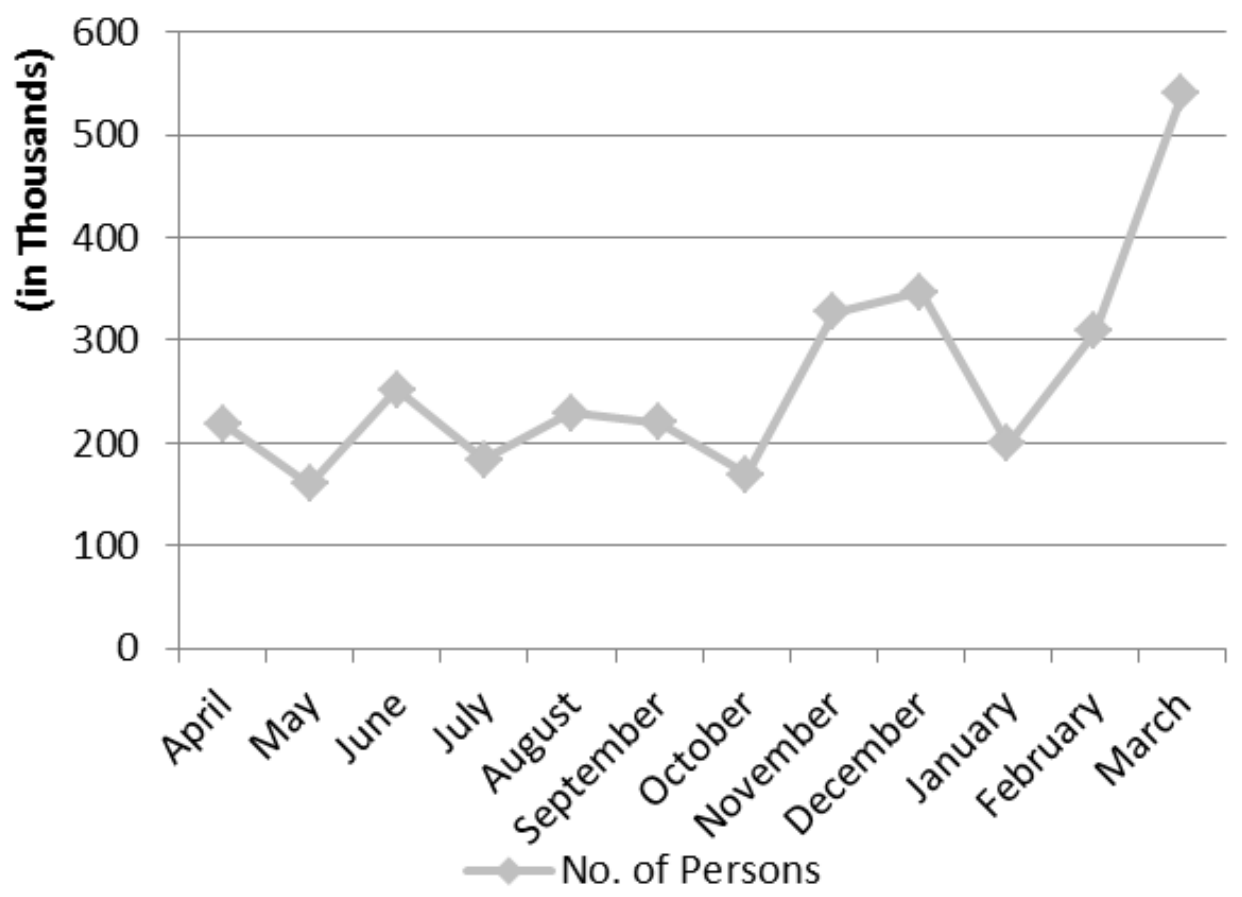

Demand remains low during peak agricultural season (April to October) and rises steeply in agricultural lean season (November to March). ${ }^{8}$ Hence, it is concluded that majority of householdsthat havesoughtemploymentunder NREGA are engaged in agriculture (either as cultivators or as agricultural labourers) who are prone to seasonal unemployment and seek employment under NREGA during agricultural off-season. In addition, this distinct seasonality also indicates that non-farm occupation holders are numerically less among NREGA participants.
To gain more insight, the months of the year can be grouped into 'peak' (March), 'moderate' (November,December,February) and 'Iow' (the remaining eight months). Table 3 presents the distribution of number of days of employment provided in different months in the respective groups. It can be easily seen that the peakseason monthsnot only see highernumber of persons employed but also higher share in total days of employment provided in the year. Table 4 presents the average persondays of employment provided under NREGS in each of 
these sub-groups. It can be clearly seen that the persondays of work are substantially higher in the periods classified as peak and moderate. However, there is not much difference in the average persondays generated 'per person'. This

Table 3: Days of Employment in NREGA Across Different Agricultural Seasons

\begin{tabular}{llcc}
\hline Season & Month & $\begin{array}{c}\text { Persondays of } \\
\text { Employment }\end{array}$ & $\begin{array}{c}\text { Share in Total } \\
\text { Persondays in a Year (\%) }\end{array}$ \\
\hline Peak & March & 5651651 & 17.99 \\
Moderate & November & 3221151 & 10.25 \\
& December & 3306610 & 10.53 \\
Low & February & 2937054 & 9.35 \\
& April & 2301851 & 7.33 \\
& May & 1596010 & 5.08 \\
& June & 2724777 & 8.67 \\
& July & 1821915 & 5.80 \\
& August & 2176931 & 6.93 \\
& September & 2053165 & 6.54 \\
& October & 1579610 & 5.03 \\
& January & 2045473 & 6.51 \\
\hline
\end{tabular}

Table 4: Average Employment in NREGA Across Different Agricultural Seasons

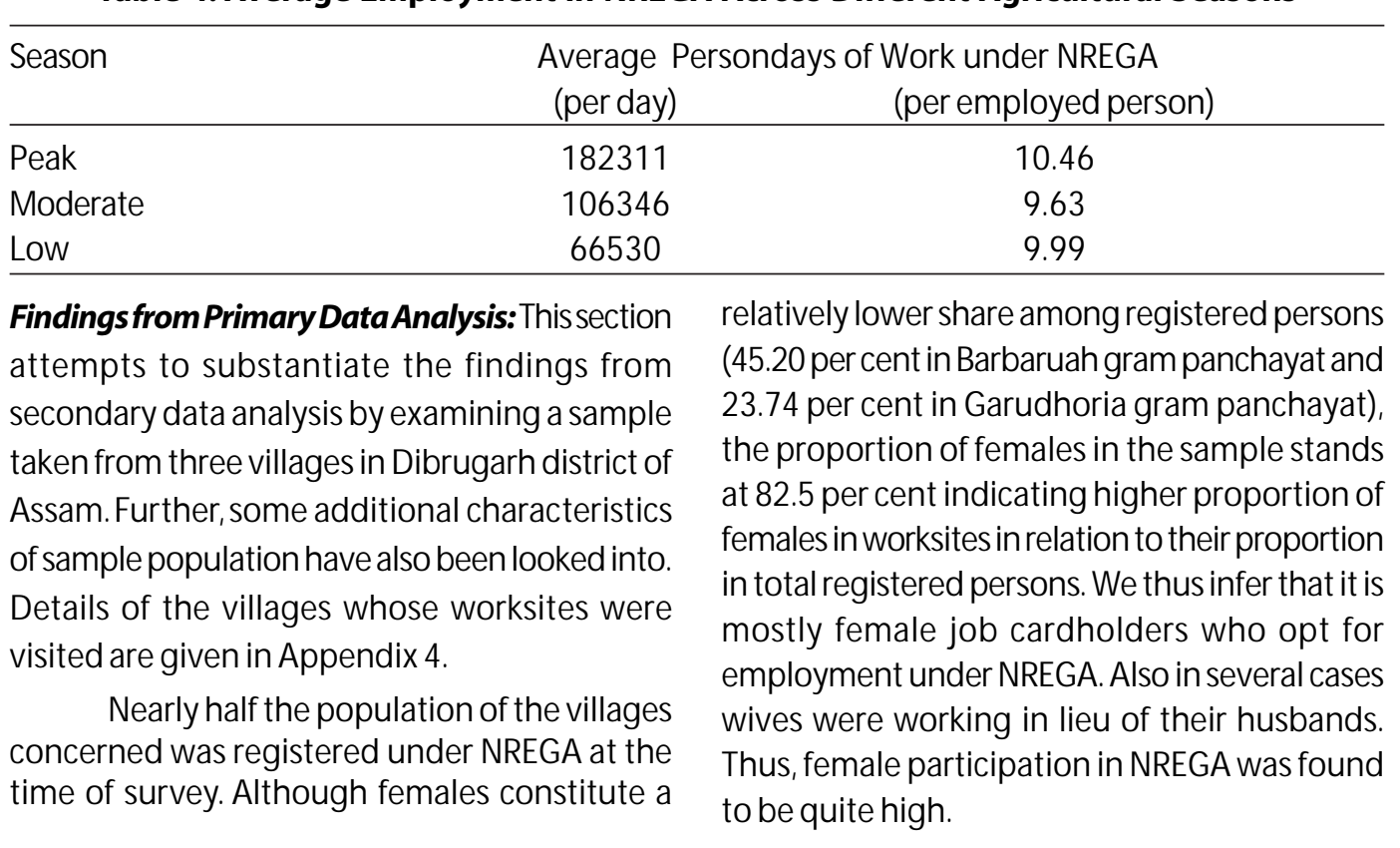

Journal of Rural Development, Vol. 36, No. 2, April - June : 2017 signifies that most of the increase in demand for work comes from a higher number of persons demanding employment in these monthsand is not because of the already engaged persons demanding more work in terms of number of days of work. 
Table 5: Summary of Socio-economic Characteristics of the Sample

\begin{tabular}{lcc}
\hline Characteristic & Number & Per cent \\
\hline Household Characteristics & 38 & (Households) \\
BPL & 46 & 60 \\
Kachcha House & 5 & 73 \\
Semi-pucca house & 42 & 8 \\
Self owned & 21 & 67 \\
Quarter & 18 & 33 \\
None of considered assets owned & 37 & 29 \\
Bicycle owned & 6 & 59 \\
Motorcycle/scooter owned & 24 & 10 \\
TV owned & 2 & 38 \\
All of considered assets owned & 3 & 3 \\
No separate kitchen & 29 & 5 \\
No proper kitchen & 52 & 46 \\
No toilet & 21 & 83 \\
Cultivating HH with harvest not sufficient & 51 & 33 \\
Child education & 45 & 81.0 \\
Female literacy & & 71.4 \\
Personal Characteristics & (Persons) & \\
Illiterate & 23 & 36.5 \\
Agri occupations & 52.0 & 82.5 \\
Marginal farmer & 21 & 33 \\
Marginal with land <2 bighas & 10 & $47.6 *$ \\
Tenant Cultivator & 7 & 11 \\
\hline
\end{tabular}

*out of total marginal farmers.

Table 5 provides details of select socioeconomic characteristics of the sample, which show high conformity to findings presented in the previoussection.

Clearly, majority of workers in the sample live in kachcha houses and are from households below official poverty line for rural Assam. ${ }^{9}$ Most respondents come from households that have no proper kitchen (46 per cent) or latrine/toilet facility within premises ( 83 percent), but possess at least one of the considered assets (71 percent). Also, it is found that for 33 per cent of sample households who cultivateland, the harvest is not sufficient to feed them for the entire year.These findings indicate that most NREGA participants belong to households of poormaterial conditions.

Another observation from the sample is that dependency is high in most participant households as average number of regular income earners per household is low at just around one. 
The ratio of non-earner to regular income-earner household member stands high at around 3.5. Again, around 35 per cent (more than $1 / 3^{\text {rd }}$ ) of respondents belonged to households with no regular income-earners.

As regardseducation, it is mostly persons with very low levels of formal education who are coming to NREG works. Although over 63 per cent of the sample population reported as literates, a large fraction (49.2 per cent) of them is below matriculation. Especially,more than half (62.2 per cent) of literate females are below matriculation. This may explain the finding in section 1 that illiteracy is negatively significant at the national level. Interestingly, most sample households encourage child and female education as proportions of households with atleast one literate child or literate female are quite high at 81 and 71 per cent, respectively. Table 6 gives details of level of education of sample population.

Table 6: Level of Education of Respondents

\begin{tabular}{lcc}
\hline Level of Education & No. & Per cent \\
\hline Under matriculation & 31 & 49.2 \\
$X^{\text {th }}$ pass & 4 & 6.3 \\
HSpass & 5 & 7.9 \\
Illiterate & 23 & 36.5 \\
Child education & 51 & 81.0 \\
Female literacy & 45.0 & 71.4 \\
Female (undermatriculation) & 28.0 & $62.2^{*}$ \\
\hline
\end{tabular}

Coming to occupation of respondents, most of them were engaged in multiple activities, with several households engaged in both agricultural as well as non-agricultural activities simultaneously. However, 84 per cent of respondents were engaged in agriculture-related occupations. Detailed information about occupations of sample households is in Figures 4 (a) and 4 (b). However, it needs to be recognised that persons from non-agricultural occupations to o have taken up NREG employment. Also, most respondents were casual labourers either in agricultural (55.6 per cent) or non-agricultural activities (31.7 per cent). Thus, it is inferred that persons without stable income source are taking to NREGS.

\section{Figure 4: Households Engaged in (a) Agricultural Occupations and (b) Non-Agricultural} Occupations

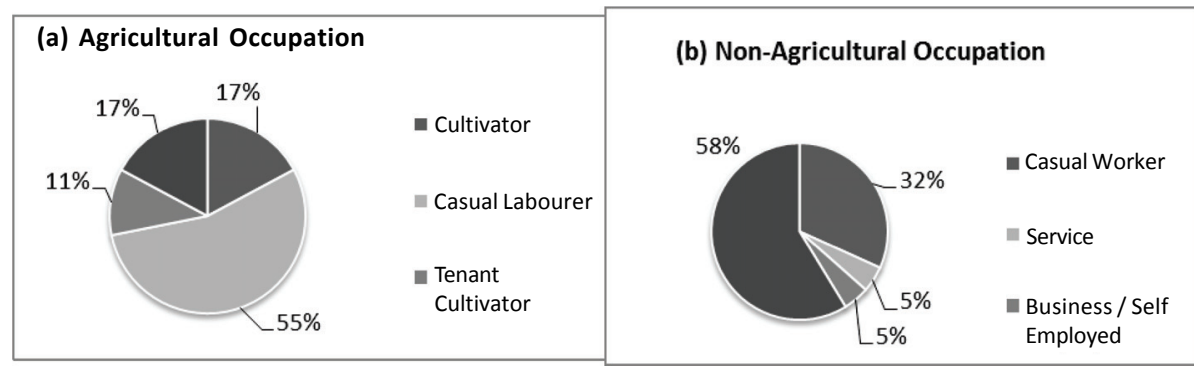

Journal of Rural Development, Vol. 36, No. 2, April - June : 2017 
Male-female differences could be observed in relation to occupation too. A large fraction (44 per cent) of female respondents reported as not working anywhere apart from NREGS. The same figure for males is zero (0),i.e., all male respondents were engaged in some other alternative incomesource. Thus, it is inferred that the scheme is reaching out to that section of females who would not have taken up any employment in the absence of NREGS.

Analysis of sample data also shows that most of the respondents are young; mean age is around 34 years, while 58.73 per cent fall in the age group of 25-45 years. Thus, participation in NREGA is highest from working age population. Moreover, females coming to work are young and are of 32.75 years age when compared to males (40.91 years).

Finally, a summary of findings from focus group discussion (FGD) conducted with key informants as well as observations made by the author during field visits are presented here.

Total Job Cardholders vs Actual Workers: FGD revealed that NREGA job cards were opted by several households for reasons other than seeking employment (like identity proof), as it is easier to obtain than other formal documents. Thus, 'total registered households' is an overestimate of persons who have really opted for NREGS in need of alternative income source.

BPL Participation: Several households with per capita consumption expenditure level below official poverty line did not have BPL cards. Because of this, participation of BPL families in NREGA gets underestimated when calculated from official records in NREGA website.

Reasons for Demanding Employment:Common reasons cited by respondents (arranged in order of decreasing frequency) were:

(i) Low household income (90.5 percent)

(ii) No or too few regular income earners in the household (83 percent)

(iii) To be self-dependent (in case of women) (9.6 per cent of female respondents)

(iv) To afford children's education

\section{Conclusion}

The study has drawn several key inferences about socio-economic factors exercising influence on participation in NREGA. Participation was higher in poorer and less developed, on the onehand, and in regionswhere NREGS has been operational for a longer duration of time, on the other. Participation was higher from materially poor households reflected by parameters like absence of latrine facility within premises and no access to banking facilities. Participation was also found to be high from socially underprivileged sections (SCs and STs). In addition, primary data show that majority of NREGS participants have monthly per capita consumption below official poverty line for rural Assam. As regards literacy, primary data showed that it was persons with very low levels of formal education who took to NREGS. Other common features of NREGS participants include relatively higher participation from households with lack of regular / stable income sources and high dependency ratio. Out of the working population, participation was highest by those engaged in agriculture, on the one hand and as casual labourers (both agricultural and non-agricultural), on the other.Again,through primary data analysis gender was found to be another important determinant of demand for NREGS employment. More female job cardholders opted for employment under NREGS relative to the male 
job cardholders. Males, on an average, came from households having greater need for alternate income sources from its members.

To conclude,targeting of NREGS has been found to be fairly efficient as it has reached several sections of its intended beneficiaries, i.e., persons (and households) in dire need of some alternative income source in rural areas. The primary data analysis, even though limited in sample size, has pointed out several important aspects which could not have been without its aid. Hence, a more extensive and rigorous study on primary data from Assam is required to obtain a clearer picture of ground realities in the State.

\section{NOTES}

1 In 2009, NREGA was renamed as Mahatma Gandhi NREGA. The terms NREGA, MGNREGA, NREGS, and MGNREGS mean more or less the same (with the first two referring to the Act on which the scheme is based).

2 Calculated from State Primary Census Abstract, Census of India, 2011.

3 Marginal landholdings are defined as landholdings that are less than one hectare in size.

4 On August, 2015, five new districts were announced in the State taking the total number to 32.

5 Population aged 18 and above was calculated from Census data on Single Year Age Returns.

$6 \quad$ NREGA was implemented in three phases across the country with the most backward districts covered in the earlier phases. In Assam, Phase I covered seven districts (Bongaigaon, Dhemaji, Goalpara, Karbi Anglong, Kokrajhar, Lakhimpur, NC Hills), Phase II covered six districts (Barpeta, Cachar, Darrang, Hailakandi, Marigaon, Nalbari) and Phase Il covered the remaining (Baksa, Chirang, Dhubri,Dibrugarh,Golaghat,J orhat,Kamrup,Kamrup (metro),Karimganj,Nagaon, Sivasagar,Sonitpur, Tinsukia, Udalguri).

7 The assets considered are radio, bicycle, scooter, motor-cycle/moped, television, laptop/computer, telephone, mobile phone.

8 Kharif is the main agricultural season in Assam. Rabi cultivation is not very widespread in Assam.

$9 \quad$ Latest official poverty line for rural Assam as per Tendulkar Methodology is ₹ 691.7 per capita per month (Planning Commission, Government of India). 


\section{Appendices}

\section{Appendix 1: NREGA Worksites Surveyed}

Table A.1: Details of the Works Visited During Field Survey

\begin{tabular}{llccc}
\hline Work Code & Name of Work & Village & $\begin{array}{c}\text { Estimated } \\
\text { Time (days) }\end{array}$ & $\begin{array}{c}\text { Employment } \\
\text { (persondays } \\
\text { per day) }\end{array}$ \\
\hline RC/116901 & $\begin{array}{l}\text { Construction of Gohain Gaon } \\
\text { SaikiaPath with Gravelling \& } \\
\text { Culvert }\end{array}$ & $\begin{array}{c}\text { Changmai } \\
\text { Gohain Gaon }\end{array}$ & 52 & 168 \\
DP/38707 & $\begin{array}{l}\text { Development \& Earth-filling } \\
\text { Burial Ground and Tea } \\
\text { Plantation }\end{array}$ & $\begin{array}{l}\text { Borbaruah } \\
\text { Tea-Estate } \\
\text { (TE) Line No.4 }\end{array}$ & 12 & 169 \\
RC/111069 & $\begin{array}{l}\text { Construction ofSubhasuk } \\
\text { Harbojanin High School }\end{array}$ & Subhashouk & NA & NA \\
& & &
\end{tabular}

\section{Appendix 2: Adjustments to Data}

(a) Census Data: Census data (2011-12) and NREGA data (2012-13) were made comparable by adjusting census population figuresforgrowth asper compounded annual growth rate (CAGR) of population of each district computed for period from 2001-2011 from the two Censuses. (Table A.2). The formula used:

$$
\mathrm{Pop}_{2012-13}=\mathrm{Pop}_{2011-12} \times \mathrm{e}^{\mathrm{rt}}
$$

Where, $r=$ annual rate of growth.

$$
\mathrm{t}=\text { time }
$$

Again, data for illiterates and non-workers was modified by subtracting population below age of 7 years.

(b). NREGA Data: The study used the number of people who 'actually worked' as a proxy for number of people 'seeking employment'in analysis due to gaps in data relating to latter in several districts. From data available through MIS, it isseen that in every district employment has been provided to almost all (98-100 per cent) of those who had demanded employment under NREGA (Table A.2). 
Table A.2: Adjustments to Data

\begin{tabular}{|c|c|c|c|c|c|c|c|}
\hline \multicolumn{4}{|c|}{ CAGR computation from census data } & \multicolumn{4}{|c|}{$\begin{array}{c}\text { Employment to Persons Demanding } \\
\text { Employment }\end{array}$} \\
\hline & \multicolumn{2}{|c|}{ Rural Population } & \multirow{3}{*}{$\begin{array}{l}\text { Decadal } \\
\text { Growth }\end{array}$} & \multirow[t]{3}{*}{ CAGR } & \multicolumn{3}{|c|}{ Total persons } \\
\hline & & & & & \multicolumn{3}{|c|}{$2012-13$} \\
\hline & & & & & \multicolumn{3}{|c|}{ Worked } \\
\hline District & $2001^{*}$ & 2011 & (in \%) & (in \%) & $\begin{array}{l}\text { Demanded } \\
\text { emp }\end{array}$ & No. & $\begin{array}{c}\text { As } \% \text { of } \\
\text { persons } \\
\text { demanding } \\
\text { emp }\end{array}$ \\
\hline Baksa & 846878.3 & 937833 & 10.74 & 1.03 & 104091 & 103905 & 99.8 \\
\hline Barpeta & 1273383 & 1546269 & 21.43 & 1.96 & 33378 & 32707 & 98 \\
\hline Bongaigaon & 521597.1 & 628994 & 20.59 & 1.89 & 57505 & 57413 & 99.8 \\
\hline Cachar & 1182422 & 1421153 & 20.19 & 1.86 & 39599 & 39422 & 99.6 \\
\hline Chirang & 401315.8 & 446825 & 11.34 & 1.08 & 45910 & 45831 & 99.8 \\
\hline Darrang & 714466 & 873006 & 22.19 & 2.02 & 21170 & 21019 & 99.3 \\
\hline Dhemaji & 531672.9 & 637848 & 19.97 & 1.84 & 83581 & 82650 & 98.9 \\
\hline Dhubri & 1402730 & 1745557 & 24.44 & 2.21 & 65660 & 65517 & 99.8 \\
\hline Dibrugarh & 967302.5 & 1082605 & 11.92 & 1.13 & 63458 & 63180 & 99.6 \\
\hline Goalpara & 709492 & 870121 & 22.64 & 2.06 & 81126 & 80453 & 99.2 \\
\hline Golaghat & 859558.3 & 969152 & 12.75 & 1.21 & 31095 & 30412 & 97.8 \\
\hline Hailakandi & 503216.1 & 611156 & 21.45 & 1.96 & 39156 & 38941 & 99.5 \\
\hline Jorhat & 797476.9 & 871722 & 9.31 & 0.89 & 45583 & 41697 & 91.5 \\
\hline Kamrup & 1188649 & 1375148 & 15.69 & 1.47 & 33706 & 33622 & 99.8 \\
\hline Kamrup & & & & & & & \\
\hline Metropolitan & 183308.3 & 216927 & 18.34 & 1.7 & 9068 & 8972 & 98.9 \\
\hline Karbi Anglong & 717253.8 & 843347 & 17.58 & 1.63 & 75150 & 74921 & 99.7 \\
\hline Karimganj & 917954.1 & 1118986 & 21.9 & 2 & 12255 & 12200 & 99.6 \\
\hline Kokrajhar & 790990.4 & 832201 & 5.21 & 0.51 & 117393 & 116709 & 99.4 \\
\hline Lakhimpur & 811127.8 & 950804 & 17.22 & 1.6 & 39260 & 39114 & 99.6 \\
\hline Morigaon & 716819.4 & 884125 & 23.34 & 2.12 & 87628 & 87059 & 99.4 \\
\hline Nagaon & 2011667 & 2454234 & 22 & 2.01 & 101545 & 101135 & 99.6 \\
\hline Nalbari & 615152.2 & 688909 & 11.99 & 1.14 & 18864 & 18691 & 99.1 \\
\hline NCHills & 133180.8 & 151613 & 13.84 & 1.3 & 9185 & 9163 & 99.8 \\
\hline Sivasagar & 951164.1 & 1040954 & 9.44 & 0.91 & 73915 & 73602 & 99.6 \\
\hline Sonitpur & 1514725 & 1750265 & 15.55 & 1.46 & 120597 & 116887 & 96.9 \\
\hline Tinsukia & 920746.5 & 1063186 & 15.47 & 1.45 & 36133 & 36132 & 100 \\
\hline Udalguri & 724472.2 & 794094 & 9.61 & 0.92 & 41273 & 41189 & 99.8 \\
\hline
\end{tabular}

Journal of Rural Development, Vol. 36, No. 2, April - June : 2017 


\section{Appendix 3: Details of Linear Regression Model}

Estimating influence of socio-economic characteristics on NREGA participation at National level

$$
\mathrm{Y}=\beta_{0}+\beta_{1}\left(\mathrm{X}_{1}\right)+\beta_{2}\left(\mathrm{X}_{2}\right)+\ldots \ldots \ldots \ldots \ldots \ldots+\beta_{15}\left(\mathrm{X}_{15}\right)+\beta 1_{16}\left(\mathrm{X}_{16}\right)+\mu
$$

Where,

Y: Percentage of rural population worked under NREGA in 2012-13 in district

$\mathrm{X}_{1}$ : Percentage of houses classified as dilapidated in district (Houses dilapidated)

$\mathrm{X}_{2}$ : Percentage of households (hh) having none of considered household assets (No assets owned)

$\mathrm{X}_{3}$ : Percentage of hh with non-availability of latrine facility within premises (No latrine facility)

$\mathrm{X}_{4}$ : Percentage of $\mathrm{hh}$ with no access to banking facility (No banking facility access)

$\mathrm{X}_{5}: \quad$ Percentage of illiterate persons (above age of 6 years) in rural regions of district (Illiterates)

$\mathrm{X}_{6}: \quad$ Percentage population of Scheduled Castes (SCs) in rural regions of district (SC)

$\mathrm{X}_{7}$ : Percentage population of Scheduled Tribes (STs) in rural regions of district (ST)

$X_{8:} \quad$ Percentage of agricultural labourers in total workers in rural regions of district (Agri labourers)

Appendix 4: Details of GP, Villages and Worksites Visited

\begin{tabular}{lcccccc}
\hline & & \multicolumn{3}{c}{ Registered Persons* } & \multicolumn{3}{c}{ Worksite Visited } \\
\cline { 3 - 7 } \multicolumn{1}{c}{ Area } & $\begin{array}{c}\text { Total } \\
\text { Popn. }\end{array}$ & $\begin{array}{c}\text { Tot } \\
\text { (\% of } \\
\text { popn) }\end{array}$ & $\begin{array}{c}\text { Females } \\
\text { (\% of tot } \\
\text { reg) }\end{array}$ & $\begin{array}{c}\text { Workers } \\
\text { Engaged* }\end{array}$ & $\begin{array}{c}\text { Workers } \\
\text { Interviewed }\end{array}$ & $\begin{array}{c}\text { Females } \\
\text { Interviewed }\end{array}$ \\
\hline Barbaruah GP & 1812 & $819(45)$ & & & & \\
Barbaruah Gaon TE(Line no.4) & 639 & $278(44)$ & $153(55)$ & 52 & 26 & $19(73)$ \\
Changmai Gohain Gaon & 961 & $297(31)$ & $109(37)$ & 67 & 16 & $13(81)$ \\
GarudhoriaGP & 3359 & $833(24)$ & & & & \\
SubhasukGaon & 901 & $374(42)$ & $108(28)$ & 60 & 21 & $20(95)$ \\
\hline Total & 949 & $370(40)$ & & 63 & $52(82.5)$ & \\
\hline
\end{tabular}

*As reported on the respective days of visit to the worksite in November, 2013.

Source: Compiled from the worksites and the Gram Panchayat Offices of Barbaruah GP and Garudhoria GP, Barbaruah Block, Dibrugarh, Assam.

Note: Figures in parentheses indicate percentages.

Journal of Rural Development, Vol. 36, No. 2, April - June : 2017 


\section{References}

1 Bordoloi, Jotin (2011), "Impact of NREGA on Wage Rates, Food Security and Rural Urban MigrationA Study in Assam", Study No. 138, Agro-Economic Research Centre for North East India, Assam Agricultural University, Assam.

2 Census of India (2011), "Houselisting and Housing Data," New Delhi, Government of India.

3 Census of India (2011), "Primary Census Abstract," New Delhi, Government of India.

4 Directorate of Economics and Statistics, Assam, Government of Assam.

5 Dreze, Jean and Reetika Khera (2009), "The Battle for Employment Guarantee", Frontline, 26(1) [accessed July 10, 2013: http://www.flonnet.com/fl2601/stories/20090116260100400.htm]

6 Drèze, Jean and Christian Oldiges (2007), "How is NREGA Doing?,, 2007 [Retrived from the web]

7 Dutta, P.; R. Murgai; M. Ravallion and D. Van De Walle (2012), “Does India's Employment Guarantee Scheme Guarantee Employment?,"Economic and Political Weekly, XLVII(16), 55-64.

8 Government of Assam, “Economic Survey, Assam, 2013,” Guwahati.

9 Gram Panchayat Office, Barbaruah Gram Panchayat, Dibrugarh, Assam.

10 J ha R., R. Gaiha,S.Shankar (2008), "Reviewing the National Rural Employment Guarantee Programme”, Economic and Political Weekly,43(11),44-48.

11 Ministry of Rural Development (MoRD), (2013), "NREGA Report," Retrieved October 2, 2013, from Mahatma Gandhi National Rural Employment Guarantee Act 2005: http://nrega.nic.in/.

12 Ministry of Statistics and Programme Implementation (MoSPI), (2013), "State-wise SDP," Retrieved October 15, 2013 from Ministry of Statistics and Programme Implementation, Government of India: http://mospi.nic.in/Mospi_New/upload/State_wise_SDP_2004-05_14mar12.pdf.

13 Singha, K., \& P. Boroowa (2013), "Performance of Centrally Sponsored Schemes: A Case of MGNREGA in Assam, India," Paper published in Conference Proceedings of UGC and ICSSR Sponsored National Seminar at Amguri College held on 25-26 October, 2013 (pp. 1-19), Amguri, Amguri College. 